\title{
Images of God in Toba Batak storytelling
}

\author{
JOHANN ANGERLER
}

\begin{abstract}
This paper examines the ways in which God the Creator, the High God, is described in Toba Batak folk-tales. The sources for this investigation are stories recorded in pre-colonial (around 1850), colonial and post-colonial times (up to 2014). In different stories the High God can appear under various names, forms and gender, and resides in various places never inhabited by humans. Unlike a Deus otiosus, the Toba Batak High God is not "inactive" after creation, but continues to be involved in the life of mankind through local or supra-local manifestations. Although he rules the realm of death, he is nevertheless regarded as the source of life, fertility, health and prosperity. There are also stories about manifestations of God in which he shares the experience of suffering with human beings. The main Toba Batak community rituals in pre-colonial times were addressed to a manifestation of the High God.

KEYWORDS

Toba Batak stories; oral tradition; ritual; High God; manifestations of God; history of religion.
\end{abstract}

\section{INTRODUCTION}

I would like to prelude my paper with two quotations. Both are from Toba Batak peasants, simple men not shamans or other Batak intellectuals. In September 1990 I had the opportunity to witness a ritual buffalo sacrifice in a village in Limbong, on the slopes of the holy mountain Pusuk Buhit, situated on the western shore of Lake Toba. The purpose of this ritual was to worship the sombaon Raja Uti. Sombaon means: 'the spiritual being who is to be worshipped'. During the following days, I visited the participants and questioned them about the purpose of the ritual. A matter not to be undertaken lightly by them as participating in the ritual entailed a temporary church ban for Protestant

JOHANN ANGERLER (PhD University of Leiden) is an independent researcher associated with the KITLV. He was previously associated with the Leiden Ethnosystems and Development Programme (LEAD), Faculty of Science, University Leiden and is author of Bius, Parbaringin und Paniaran; Über Demokratie und Religion bei den Toba Batak Nordsumatras (2009). His main research interest is concerned with Sumatran cultures, especially traditional political and religious institutions. Johann Angerler may be contacted at: johann.angerler@gmail.com. 
members of the community. Furthermore, it was a costly undertaking. Why did they take the risk and be willing to spend their money on something in which they were not supposed to believe? One member of the host party told me very seriously: "You know, formerly God was always much closer to us". By performing the ritual, they were once again able to experience that feeling of closeness to God, he explained. Nevertheless, I found it very difficult to understand the meaning behind it all properly. Was the sombaon Raja Uti, the spiritual being they worshipped, God?

I heard the second quotation in the Sihotang Valley, several kilometres south of Limbong, where a father described to me how his son had been cured. For years, the son had been afflicted by mental illness but performing a healing ritual and praying to God had finally achieved a permanent cure. When I asked the man to be more specific about what he meant by God, he told me in a mixture of Batak and Indonesian: Tuhan Yang Maha Esa na maringanan dison (I prayed to Tuhan Yang Maha Esa who lives over there), and pointed towards a specific part of the forest which was thought to be the dwelling place of the sombaon Baganding Tua Saranggean Pardosi. In the national Indonesian context, Tuhan Yang Maha Esa denotes the One and Only Almighty God, in whom belief is required by the Pancasila, the basic principles of Indonesian state ideology. So, why did this villager say that Tuhan Yang Maha Esa dwelt in the forest in which the sombaon Baganding Tua lives? It took me some time to understand fully the importance of the clues my informants had given me.

Since then I have collected and studied many stories about Raja Uti and Baganding Tua and these have enabled me to understand that both Raja Uti and Baganding Tua are God. Not two different Gods, but rather, two manifestations of the Toba Batak High God. Raja Uti can assume several different forms. He is usually described as having a human body and either the head of a pig (ulu ni babi) or just the snout of a pig (muncung ni babi). Furthermore Raja Uti can also assume the form of a serpent or a dragon. In fact, Raja Uti can even be a woman. ${ }^{1}$ Raja Uti has many names and one of them is Baganding Tua. He is regarded as the source of the spirituality of the sacral kings of the Toba Batak, Singamangaraja, Ompu Palti Raja, and Jonggi Manaor. In the stories he can reside either outside the Batak region (frequently mentioned places are: Barus, Mursala Island, Aceh, Riau, and the Minangkabau area) or within the Batak Lands. The region of the holy mountain, Pusuk Buhit, is thought to be his residence. There he rules the realm of death, governing it with what is described as a cabinet composed of sombaon, the souls of spiritually important deceased humans.

In Sihotang Baganding Tua is described as a motionless, gigantic serpent whose always-open jaws are so big they can serve as an entrance for an elephant or a deer. ${ }^{2}$ There the local people believe that when animals grow

1 The first to give me this information was the datu partonggo (shaman specialized in ritual prayers) Ama Juang Naibaho, at the time a well-known expert in regional mythology and ritual.

The image of a deer and an elephant was frequently used by my informants in Sihotang 
old and wish to die, they willingly enter the mouth of Baganding Tua. Paradoxically the realm of death, which is inside the body of Baganding Tua Saranggean Pardosi, is also the source of life, fertility, health and prosperity, an idea expressed in the word tua. The final part of the name, pardosi, can be translated as 'the one who makes all equal'. The first part of the name, baganding, means, 'having (white) spots'.

In former times the main community rituals of the region, especially the great buffalo sacrifice rituals of the bius, the community of the whole valley, were addressed to Baganding Tua (see Illustration 1$).^{3}$

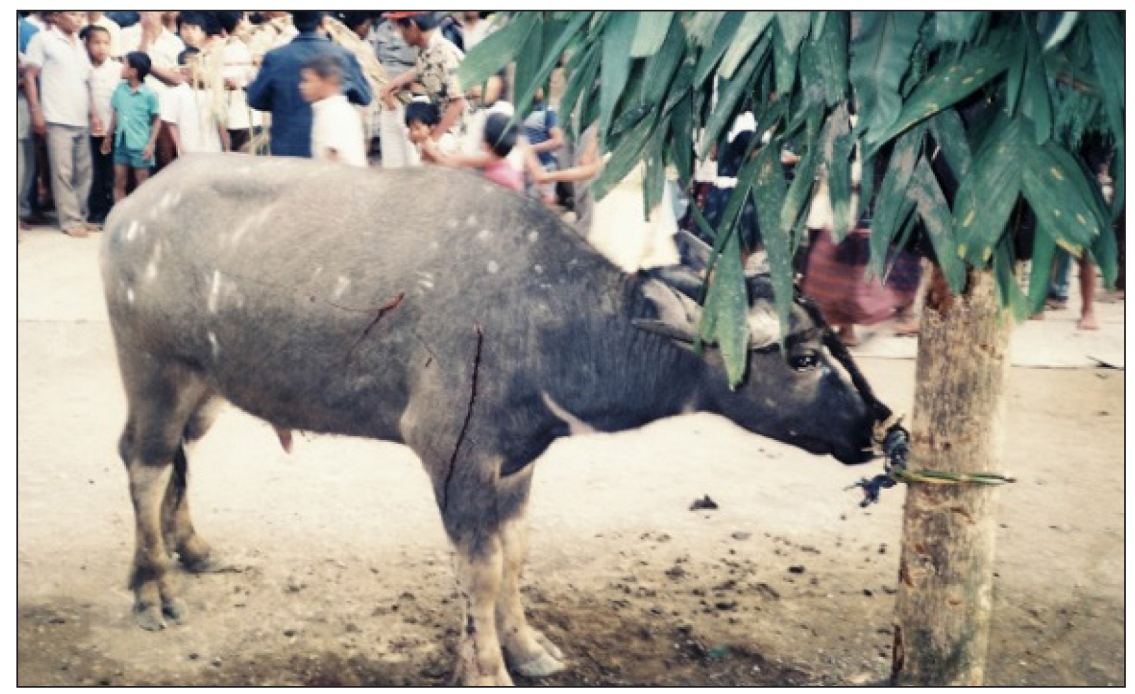

Illustration 1 . The sacrificial buffalo daubed with white rice flour becomes Baganding Tua, the "spotted bringer of luck" during the ritual (photograph by the author in Limbong, western shore Lake Toba, 1990).

\section{Who is Mulajadi Nabolon, the RENOWNEd TOBA BAtAK HigH GOD?}

As said, at least two manifestations of God, in different images or forms, are still actively worshipped in the Batak region. The stories about Raja Uti especially are very much alive; they are still told and even printed in newspapers and published on the Internet.

At this point a reader familiar with present-day popular Toba Batak culture might raise the question: "Don't the Toba Batak call their indigenous High God Mulajadi Nabolon?" The name Mulajadi Nabolon denotes origin (mula), becoming (jadi), and greatness (bolon). Mulajadi Nabolon is emphatically present on the Internet and scores many hits on Google. Mulajadi Nabolon

to describe the magnitude of Baganding Tua's mouth.

3 For an extensive analysis of bius as a form of socio-political organization and its rituals see my book, Angerler (2009), Situmorang $(1993,2004)$, and the description and analysis of a buffalo sacrifice ritual in Korn (1953). 
is the Tuhan Yang Maha Esa in the eyes of the adherents of the Parmalim religion $^{4}$ and those of tourism promoters. Importantly, although Mulajadi Nabolon might be viewed differently by Protestants and Roman Catholics, everybody seems to agree that $\mathrm{He}$ is the indigenous Toba Batak High God. He is described as the Creator of the Three-layered Cosmos and, according to the Indonesian Wikipedia, his wife, Manuk Patiaradja, is imagined as the blue chicken which laid the three eggs, from which were hatched the three human Gods, Batara Guru, Soripada and Mangalabulan, the Upperworld ancestors of mankind. This conception leaves little doubt that Mulajadi Nabolon is male and he is the source and origin of everything.

\section{PHILIP LUMBAN TOBING: THE HIGH GOD AS THE UNIVERSE ITSELF}

The idea that the Toba Batak High God is known to people under various names and appearances should come as no surprise to scholars who are familiar with the literature on traditional Batak religion. This fact was demonstrated in the 1950s by the research of Philip Lumban Tobing. Tobing, himself a Toba Batak, did his research under particularly auspicious circumstances. He had the opportunity to interview numerous learned indigenous experts on traditional Batak religion as well as various Western scholars of Batak culture, who helped him to locate relevant old Batak manuscripts. On account of his scholarly background, he knew that the people who adhered to the traditional Batak religion conceived of their High God in different images, saw God in different places and called God by different names. Tobing assumed that behind the different images was the idea of the fundamental oneness of the High God Who, in his view, "is identical with the total cosmos and order; he is omnipresent and his power is evident in everything" (Tobing 1956: 27). On the basis of this assumption, in his work he subsequently equates many more elements of Toba Batak culture with aspects or representations of the "totally immanent" High God. These elements include the tunggal panaluan (the so-called magic staff), piso and ulos, male and female gifts, dalihan na tolu, the systems of social relations, the Toba Batak house, the slaughtering pole as the representation of the cosmic tree plus many more. This point of view tallied with the development of the anthropological theory of religion at the time: compare, for example, what (his mentor) K.A. Hidding wrote with reference to Hans Schärer's book (1963) on the High God of the Ngaju Dayak (Hidding 1954: 37):

There is nothing at all, neither the way of dressing or tattooing, magic nor the way of life strictly regulated by adat (customary law) which does not derive from the holy totality, and consequently might be treated in a profane way. ${ }^{5}$

4 There are several Toba Batak religious organizations, which call themselves Parmalim, and claim that they adhere to the traditional Batak faith. For their complex history compare Masashi Hirosue $(1988,2005)$ and De Boer $(1914,1915)$.

$5 \quad$ Er is in zijn geheel niets, noch de wijze van kleden of tatoeëren, noch de magie of de door de adat streng geregelde wijze van leven, dat niet van de heilige totaliteit afkomstig is, zodat het op profane wijze zou mogen worden behandeld. 
The changes in perception of the Toba Batak High God have been enormous when we consider that in 1885 the German missionary W. Ködding declared the Toba Batak High God to be a "completely transcendent" and "personal God" (Ködding 1885: 406). Edwin M. Loeb (1935: 75) seems to follow this interpretation with his additional interpretation of the Toba Batak High God as an otiose deity, an inactive/retired God. Only Johannes Warneck actually noted that there were more conceptions of the High God (1909: 4-7, 26-39). Tobing's interpretation of the High God has been both praised and criticized by several scholars, most notably P.E. de Josselin de Jong (1957: 393-396) and Stöhr (1965: 58-60), on methodological grounds (Tobing cannot provide proof of his assertions). Harry Parkin (1978: 150) hit the nail of the problem of Tobing's interpretation on the head:

In his eagerness to find evidence both of the "primitive" totalitarian "weltanschauung", and of the Toba-Batak belief in the High God as the totality he arrives at a panentheism within which there is no valid distinction between anything.

Anicetus Bongsu Sinaga (the incumbent Archbishop of Medan) has tried to solve the problem of how to understand the High God by declaring the Toba Batak High God to be both transcendent and immanent: "The transcendence of the High God is essentially immanent and his immanence is essentially transcendent" (1981: 39).

My aim in this paper is to solve neither the dispute between the Toba Batak theologians nor the question of transcendence - immanence, instead I would like to add a view taken from a different perspective by investigating images of God in various stories about the High God from different times, and see if I can learn something from the disparate views which the participants, the storytellers, held. My hope is that by going back to these sources from different periods in time might enable me to achieve a better understanding of how present-day perceptions of the High God originated and to discover more about the background of the alternative perceptions of my informants.

\section{MulajAdi NabOlON AND THE WORK OF GURU SiNANGGA}

Despite the fact many visitors did make enquiries about God the Creator, the name Mulajadi Nabolon is not mentioned either in pre-colonial or in early colonial accounts. All these early accounts show that there was no generally agreed name for the High God in the Batak Lands. Even the German missionaries $^{6}$ did not mention Mulajadi Nabolon for many years after their arrival in the area in $1864 .^{7}$ In their work, they did not choose an indigenous

$6 \quad$ For the relationship between the German missionaries of the Rhenish Missionary Society and the Batak people see Angerler 1993.

Nowhere could I find any mention of the name Mulajadi Nabolon, either in publications of the Rhenish Missionary Society or in their archives (VEM / Vereinte Evangelische Mission). Niemann (1870), who summarized the literature on Batak religion, also does not mention this name. 
name for God but decided to designate God "Jehova" in their teaching and in their translation of the Bible.

This raises the question: How did Mulajadi Nabolon become the generally agreed name for God? Apparently it all began in 1872 when the German missionary Ludwig Ingwer Nommensen invited the storyteller and learned shaman Guru Sinangga to his house and asked him to write down some stories. Guru Sinangga did so and subsequently his origin stories, a small but important part of the whole corpus, were copied and dispersed among missionaries and intellectual Bataks. It is safe to assume that this dispersion must have helped the process of unifying the idea of the one Batak God called Mulajadi Nabolon because, within the span of the following fifteen years, the name Mulajadi Nabolon seems to have become widely known. ${ }^{8}$

\section{THE ORIGIN STORIES OF GURU SINANGGA}

In his own era (after the middle of the nineteenth century), Guru Sinangga ni Aji, of the Matondang (Pasaribu) clan (marga) from the village Sait ni Huta in Silindung (now North Tapanuli) was a renowned datu (learned shaman) and author of several pustaha (Batak bark-books) and an expert on bius rituals, then the main community rituals in Toba Batak society. Therefore, he was also an expert in and celebrated narrator of origin stories (the bius buffalo sacrifice rituals always celebrate or renew creation). When the missionary Ludwig Ingwer Nommensen invited him to write down his oral tradition in 1872, in a relatively short time he produced an extensive corpus of Toba Batak stories consisting of at least 120,000 words (the whole corpus has not been preserved). ${ }^{9}$

Most prominent in Guru Sinangga's collection are the origin stories in which Mulajadi Nabolon features as the source of creation of the human Gods and also as the source of the original matter from which the Earth on which we live was made by Boru Deak Parujar (Illustration 2), the female creator of the Earth, and ancestress of mankind. Basically Guru Sinangga's origin tales can be divided into three parts: Mula ni Jolma (origin of humans), Mula ni Tano (origin of the Earth) and Mula ni Parumaon (origin of the family/the household). ${ }^{10}$

8 In 1885 Ködding, the missionary mentioned above, describes "Mula djadi na bolon" as the highest God and sole creator of the universe and the other gods. In his description of the region of Padang Lawas, Neumann (1887: 289) mentions Mulajadi Nabolon as God the Creator, and adds that this God is completely ignored in rituals. Forty years earlier, his predecessor Willer (1846: 292) had described the High God quite differently. Religious information could travel quite fast in the pre-colonial Batak Lands, as for example the account of the Austrian traveller Freiherr von Brenner shows. During his journey to the then independent Lontung region (East Samosir) in 1887, he discovered that there had already been a considerable knowledge of the Christian religion years before the arrival of the first missionary (Von Brenner 1894: 111).

$9 \quad$ Guru Sinangga's original manuscript has not been preserved. There are several Latin transcriptions stored in the archives of the VEM in Wuppertal. It is safe to assume that a copy in Batak script, prepared by Nommensen, soon after Guru Sinangga's work was completed and sent to the linguist Van der Tuuk in the Netherlands, is closest to the original manuscript; see: Leiden University Library Cod. Or. 1260z.

10 The first two parts have been published in both Toba Batak and in English translation 


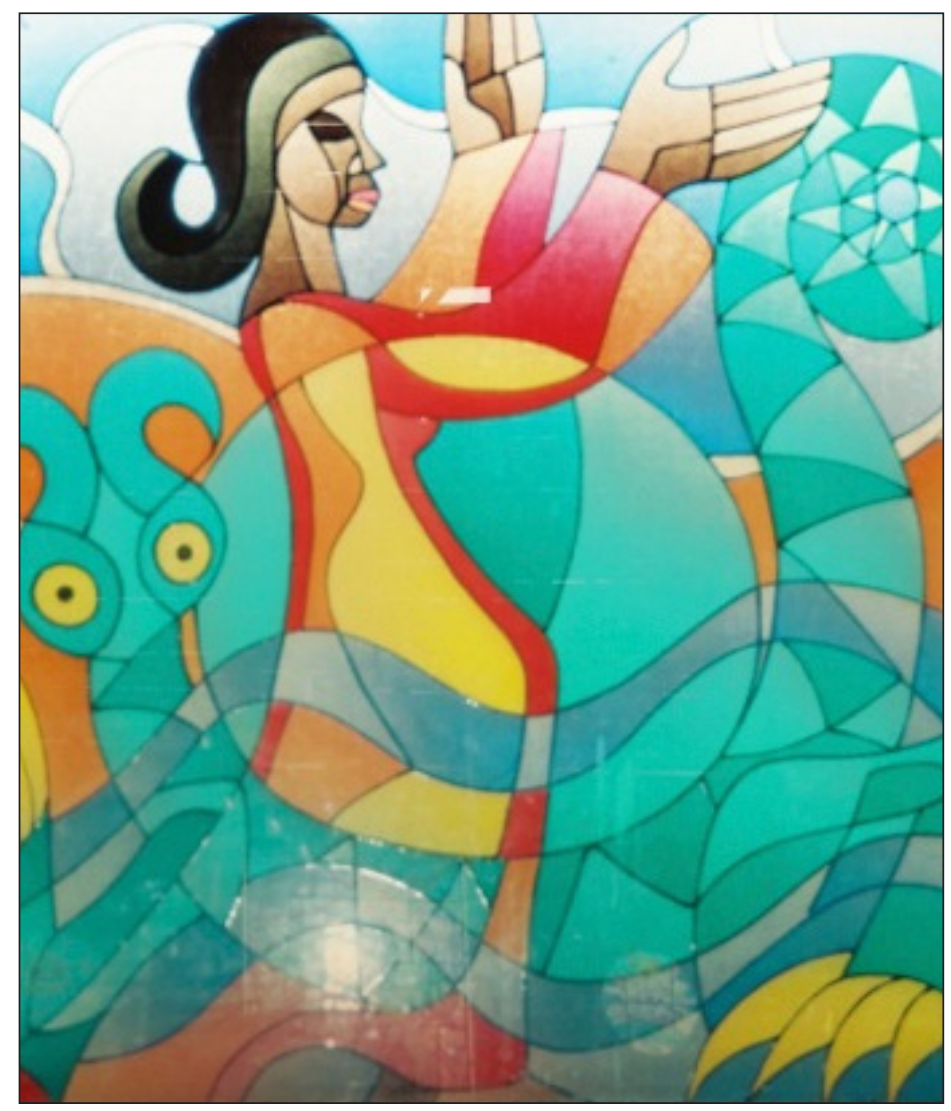

Illustration 2. Boru Deak Parujar and Naga Padoha in their epic battle for the creation of the Earth (photograph taken from a window of the Roman Catholic Church in Pangururan, Samosir, by the author, 1997).

The creation of the cosmos is passed over in these stories. It is already present as are the animals and Mulajadi Nabolon, whose appearance or form is not described. The births of the "humans" (jolma) the three Upperworld Gods Batara Guru, Soripada, and Mangalabulan, hatched from the three eggs laid by the little bird Manukmanuk Hulambu Jati, come about because Mulajadi Nabolon wills it. Mulajadi Nabolon clearly states that He Himself has "sent" the human men, and it is He who sends them women to marry. Subsequently in the Upperworld the "human" Gods, who can be considered to be a link between the High God and mankind, lead a life analogous to the Toba Batak way of life. The main part of the stories recounts the drama of the twin daughters of Batara Guru, Si Boru Sorbajati and Si Boru Deak Parujar.

in: Niessen 1985: 16-103. Sandra Niessen used one of the circulating copies of Guru Sinangga's original text; actually, the text seems to have been copied from a book. Niessen's informant, Radja Darius Sibarani, had claimed that he had copied the text from a pustaha. In fact, it is more likely that the text was copied from one of Mangaradja Salomo Pasariboe's books, published in either 1925 or 1938: 7-22. In the Leiden version of Guru Sinangga's texts, the High God Mulajadi Nabolon did not descend to Earth to give personal instruction to Boru Deak Parujar. That part is an addition to the text of the story apparently made by Mangaradja Salomo Pasariboe. 
Both refuse to marry their prospective husbands. Boru Sorbajati who wants to kill herself sinks into the ground and becomes part of the natural world. The more resourceful and astute Boru Deak Parujar escapes marriage by climbing down towards the Underworld into the primeval sea. After initial sufferings she eventually overcomes the unruliness of the powers of the Underworld and succeeds in creating the Earth by sheer hard work, shrewdness and the help of Mulajadi Nabolon. Mulajadi Nabolon continues to be involved through the agency of his messenger animals and he sends Boru Deak Parujar the iron chains she needs to subdue the Underworld dragon, Raja Padoha, who repeatedly destroys her creation; the earth matter she needs to mould it, plus the four stone and four iron pillars needed to stabilize the Earth (which is likened to a house) and finally the seeds of all the plants (see also Illustration 2).

At this point, it should be mentioned that, in this version as in most other versions of older Batak creation-stories, as the personification of a higher spiritual power, the archetypal female shaman and midwife, Boru Sibaso Paet is consulted by the main protagonists of the story in times of distress. In Sandra Niessen's dissertation, the story ends with Mulajadi Nabolon teaching Boru Deak Parujar the "science of the Earth she has created". He does so by instructing her in the words of the special shaman language (hata pangarangsaon); words which cover the essence of their referents. However, as mentioned, this part was added much later; apparently by Mangaradja Salaomo Pasariboe (1925: 27-31). Batak storytelling always seems to be a "work in progress".

Guru Sinangga's original (the Leiden manuscript version) continues with the story of Mula ni Parumaon, "Origin of the family or the household", but Mulajadi Nabolon appears only in the first two stories. At this point, it is necessary to pose the question: Should Guru Sinangga's origin stories be considered to represent an approximation of the original traditional belief of the Toba Batak? Guru Sinangga was, as mentioned, not only a skilled writer of pustaha but also a master storyteller. His traditional eloquence impressed both the Toba Batak themselves and European speakers of the Toba language. After reading his origin stories, one is tempted to answer in the affirmative (as Ködding did) that, despite indubitable Hindu influence, this definitely has to be the High God of the Toba Batak. Importantly, Guru Sinangga invokes no specific image of God in his story. Mulajadi Nabolon is in charge of Creation, it is His Will; He is abstract, divine, and quite acceptable to monotheists. In any considerations, it is important not to forget that in 1872, when Guru Sinangga wrote for Nommensen, missionaries had already been teaching the gospels in the Silindung valley for more than seven years. It is impossible to exclude the possibility their teachings might somehow be reflected in the text. Batak datu or shamans are always eager to learn something new, especially about spiritual matters, and to incorporate this into their body of knowledge. In their thinking, they are not restrained by any dogma. By that time there had also been contact with Islam, a fact which Guru Sinangga also took into consideration in his text: the firstborn son of Batara Guru is called Sori Mahumat. Admittedly, he plays no further role, but he is present. 


\section{OLDER STORIES ABOUT THE HIGH GOD}

The following two origin stories were collected approximately twenty years before Guru Sinangga committed his versions to paper. There is a very good chance that they might have been written much earlier, as both are from manuscripts collected by the linguist Herman Neubronner van der Tuuk during his research into Batak languages between 1851 and 1856.

\section{NANG GORGA DI PORTIBI AND THE High GOD MOTHER SilABI MulajADI}

The first text was transcribed by Van der Tuuk from an inscribed bamboo. ${ }^{11}$ As in other stories about the Creation of the Earth, the female protagonist is not able to create the Earth alone; she needs the help of the High God. Interestingly, in her prayer the image of the High God as female emerges: the use of inang (mother) as a term of address is quite unambiguous.

The obstinate daughter of Batara Guru and Creator of the Earth, who is known as Boru Deak/Dayang Parujar in other origin stories, is here called Nang Gorga di Portibi. Both names might carry a similar allusion, as each refers to a particular kind of skill. The word gorga denotes wood-carving, but it is also possible to say manggorga hata, 'skilled in choosing one's words'; the latter might be an indication of her skill in using language. A possible translation of the name would be, 'Woman who is a skilled speaker in the world'. The text confirms this interpretation as she is also called boru morhata-hata, na humatahon mula ni tano on, mambahen na adong tano na niipaan ni hita jolma manisia on. This can be translated as: 'Woman of the words, who brought about the origin of the Earth with her words, who made the Earth on which we humans live'. She is apparently a shaman and is also named Boru Sibaso Paet "who lives on the foam" (na mian di gubogubo). This is the name and a common attribute of the archetypal female shaman and medium who is present in most versions of the great creative undertaking of Batara Guru's daughter.

\section{Synopsis of the story in MS Or. 3401 and Meerwaldt (1904: 139-143)}

In this text Nang Gorga di Portibi is the daughter of Sutan Batara Guru Doli, who is the primus inter pares (pangulu) among the "human" Gods of the Upperworld (banua ginjang). She rejects all her proposed suitors because she loves her brother, Datu Sipitu Timpus, Datu Sirengrung Pormiahan. As an incestuous relationship could bring serious misfortune upon the community, to set everybody an example, Batara Guru casts both his children into the Underworld (banua luhung). The task of Batara Guru as pangulu ${ }^{12}$ in the Upperworld is to adhere faithfully to the law. In the Underworld, the expelled couple perch on the primeval rock, Nanggar Jati, feeling desperate. As their titles (datu and sibaso) imply, both of them are shamans, but it is Nang Gorga who thinks of a (shamanic) way out of their predicament and utters a prayer to the High God:

11 See MS Or. 3401 pp. 70-73. The text was later published in Meerwaldt (1904: 139-143).

12 For the obligations and tasks of a pangulu (also called parbaringin), the traditional hereditary leader in pre-colonial society, see Angerler 2009; specifically for Batara Guru as pangulu or parbaringin: 269-270. 
Asa ung pagari ma hami, na manda ompungku, pagari pinagaranta on, na manda ompungku Silabi. Aha ma inang, Silabi Mula Tohuk, Silabi Mulajadi? Ia hujadihon mintorangku tu mata ni ari, mata ni ari ma ho, lagia batorang, masiang, masese; ia hujadihon do mintorangku tu mata ni bulan, mata ni bulan do ho, lagia batorang, masiang, masese; ia hujadihon mintorangku tu hosa ni damang, tu hosa ni dainang, tu hosa ni ibotongku ma ho, lagia batorang, masiang, masese ma ho di toding banua ginjang.
Now, protect us, thou, who are truly my grandmother; shelter us who need to be kept safe, thou, who are truly my grandmother Silabi. What shall it be, Mother, Silabi Mula Tohuk, Silabi Mulajadi? ${ }^{13}$ If I direct my mantra towards the sun, be thou the sun, truly bright, dry and boundless; if I direct my mantra towards the moon, be thou the moon, really bright, dry and boundless; if I direct my mantra towards the life-soul (literally: breath) of my father, if I direct my mantra towards the life-soul of my mother, if I direct my mantra towards the life-soul of my brother (s), be thou (these life-souls) too, truly bright, dry and boundless, thou, who are in the Upperworld.

Through her petitions, Nang Gorga succeeds in obtaining divine help in restoring the relationship with her family in the Upperworld (although return is impossible) and subsequently she is the recipient of even more divine female help: her shamanic spirit/ familiar spirit (jujungan ni Boru Sibaso Bolon) speaks out and offers her advice on how to create the Earth. With the help of the heavenly messenger-animals (Leangleang Mandi and Untunguntung na Bolon) and the material help of her father, Nang Gorga, she finally succeeds in overcoming the resistance of Tuan Humurla, the Underworld dragon and is able to create the Earth.

The text ends with the sentence: Ale, amang tuan na torop! Greetings, listeners! This remark seems to indicate that even in pre-colonial times Toba Batak did in fact sometimes write down oral literature, especially origin stories. ${ }^{14}$ This is also the case with the next example.

\section{BORU DAYANG PARUJAR AND THE High GOD "GRANDFATHER- GRANDMOTHER" MULA HARANNA}

The text of this creation-story was transcribed from a pustaha by Van der Tuuk (MS Or. 3421). ${ }^{15}$ In it Boru Dayang Parujar encounters the High God in the Underworld. The High God's name is Mula Haranna, who is addressed as both grandfather and grandmother (ompung doli ompung boru), and is

13 Labi denotes a freshwater turtle and tohuk a species of large frog. This part of the name of God could be translated as 'Mother Turtle, Origin of the Big Frog, Turtle, Origin of Creation' (literally: origin of becoming). The image of God in this text is clearly female.

14 Similar remarks are also to be found in Dairi stories; see Brakel-Papenhuijzen 2014.

15 The original pustaha was then in the possession of Ompu ni Manunghol Langit from Aek na Uli in the Sijamapolang region. Later the pustaha was acquired by the Rijksmuseum voor Volkenkunde Leiden; see REM Nr. 129/267. 
described as having the form of a dragon (naga), with scales (sisik) and a tail (ihur). Mula Haranna not only helps Boru Dayang Parujar to create the Earth, he also finds her a husband.

In this story Boru Dayang Parujar is given the following names and attributes: "Boru Dayang Parujar who owns a jacket which enables her to fly"16 (na marbajubaju mahijang) and she "who never spins, who never fetches firewood, who never weaves" (na so ra mangganti, na so ra marsobansoban, na so ra martonun). ${ }^{17}$ Some names and attributes of the High God mentioned in this text are: "Our grandfather, our grandmother Mula Haranna"18 (ompunta doli, omputa boru Mula Haranna), 19 "origin of the Creation, origin of blessings and prosperity" (mula tompa mula gabe, or mula ni tompana mula ni gabena), "(mother) Basang Basuhi ${ }^{20}$ who is (also) every father and every ancestor" ([nae] Basang Basuhi na ganup ama na ganup ompu), "dragon who rumbles like thunder in the waterhole Nanggar Jawa" (naga na gumurut-gurut di lubuk Nanggar Jawa), "dragon who is visible once in a while in the middle of the sea (or Lake Toba)", (naga lumimbe-limbe di tonga ni lautan), "dragon endowed with spiritual power", (nagajungjung aji), "our grandmother who rolls like thunder in the waterhole of the rice stalks in the waters of Ambarita" (ompunta Boru na gumurup-gurup di lubuk batang eme di aek Ambarita), "Naga Bindu Java", "Naga Ijo", "Naga Horsik", "Naga Mangintal”, and "Naga Situllang Bosi" (see Illustration 3). ${ }^{21}$

16 Here Boru Dayang Parujar is merged with the character Boru Dayang na Gurasta or Leang na Gurasta, in some versions a sister of Dayang Parujar, who has the ability to fly; often described as an even more beautiful woman and a more skilled weaver than Dayang Parujar herself. In one version, Dayang na Gurasta acts as a trickster who lures her sister into the Underworld (see MS Or. 3454).

${ }_{17}$ This is an inversion compared with other texts in which Dayang Parujar is an accomplished weaver.

${ }_{18}$ There is no certainty about the meaning of the name Haranna. If hara is the root-word, it could mean a (big) turtle. This might be influenced by the idea of the cosmic/world-bearing turtle in Hindu and Chinese mythology. If this is correct, the name Mula Haranna could be translated as "Origin of the (Cosmic) Turtle".

19 The great expert in Batak languages Voorhoeve 1958: 243, made one of his rare mistakes when he translated these terms of address as "Mula Haranna and his wife".

20 Usually "nae" (mother) basangbasuhi; this is an expression from the shamanic language (hata pangarangsaon) and denotes 1) the square Toba Batak fireplace and 2) the square Toba Batak winnowing-basket in ritual context. Both serve as symbols of the Earth. This opens the possibility to translate (Nae) Basang Basuhi as "Mother Earth".

21 In other stories, as Naga Situllang Bosi (sometimes Naga Tuldang or Tumuldang Bosi, all signifying the same: "Dragon Iron-Piercer") the High God has granted fertility to the childless Batara Guru and his wife, thereby ensuring the birth of Boru Deak Parujar. See Angerler (1997: 413-414); Bezemer (1904: 192-195). Original information about Naga Situllang Bosi is to be found in pustaha Staatsbibliothek Berlin MS Or. 13979 (see Illustration 3). This richly illustrated pustaha is at present being investigated by Roberta Zollo, L'Orientale, University of Naples. 


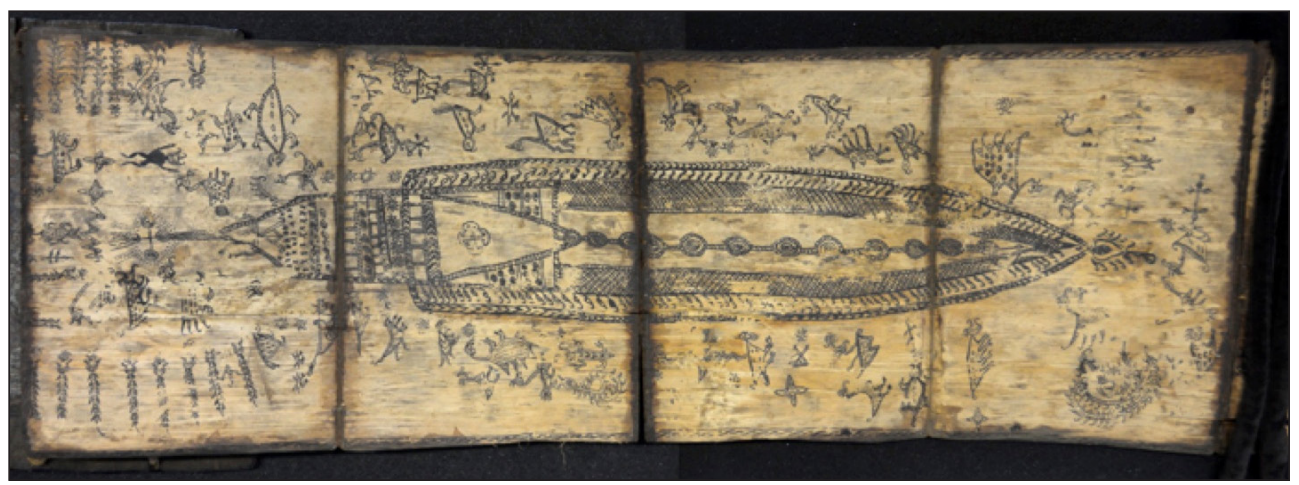

Illustration 3. A scene from a story of Naga Situllang Bosi. Illustration from pustaha Staatsbibliothek Berlin MS Or. 13979 (photograph courtesy of Uli Kozok, 2015).

Synopsis of the story in REM Nr. 129/267 and in MS Or. 3421

Boru Dayang Parujar is the daughter of Batara Guru Doli and his wife, Nai Bangun Pangisi. She is promised to the son of her paternal aunt (anak ni namboru) Mangele Bulan, whom she despises (mahilolong) and refuses to marry. In accordance with the decision of the pangulu Tangka Tolatola, the arbiter, Boru Dayang Parujar must be expelled. Her parents send her to the Underworld, but do not send her empty-handed as they also supply her with soil, medicine and useful implements.

With Boru Sibaso Paet, "who knows when people will die and who knows when people will live, created from the foam" ${ }^{22}$ (siboto halak mangolu, tinompa ni gubogubo), her supplies and the heavenly messenger animals, Layang Mandi and Raja Untunguntung, she is put onto a square iron rack (ragaraga bosi) suspended from a rope of black silk tied to the cosmic tree and lowered into the Underworld. When Batara Guru severs the rope, the two women are left exposed to the elements, adrift on the waters of the primordial sea. A messenger is dispatched back to the Upperworld to tell Dayang Parujar's parents that she is now prepared to marry her aunt's son, but there is no way back. Boru Dayang Parujar cries day and night, and her sobbing awaken the High God Mula Haranna, who comes and asks her about her troubles. When she tells Mula Haranna that she is prepared to marry Mangele Bulan's son, Mula Haranna dissuades her and offers her a better choice:

22 This might refer to older stories in which the first humans were created by the archetypal female shaman Boru Sibaso Paet by breaking an egg and releasing the egg-foam, the primordial substance of life; see letter of Van der Tuuk from 6 June 1851, published in Groeneboer (2002: 111). 
Asa laho ma, hanuhon, ompunta Mula Haranna, mula tompa, tu bona ni hayu halak, ia tu tur ditangkup babiat, ia tu aek ditangkup buaya. Asa ditangkup Mula Haranna, mula tompa, asa digoar ma hanuhon Tuan Sorimangaraja, Tuan Manulahi asa diparap ma tu raga-raga bosi tunggane ni si Dayang Parujar.
And then, it is told, our Ompung Mula Haranna, origin of the Creation, went to the trunk of the man-tree. On the dry field He/She caught the tiger, in the water $\mathrm{He}$ /She caught the crocodile. They were caught by Mula Haranna, origin of the Creation, and, as is told, He/She named them Tuan Sorimangaraja and Tuan Manulahi, and $\mathrm{He}$ /She took them to the iron rack as a husband for Dayang Parujar. ${ }^{23}$

Boru Dayang Parujar agrees to this arrangement and the newly-weds ask where they should live. Mula Haranna explains what they can do with the provisions given by Batara Guru. With the implements Tuan Sorimangaraja, her new husband, forges eightfold iron shackles, which Mula Haranna puts on the Underworld dragon, Saniang Naga Padoha, who is an obstacle to the creation of the Earth. Once he is a prisoner, the way is free for Dayang Parujar to form the Earth. Finally seeds of all the plants are created with the help and the life-giving blessings of the High God Mula Haranna.

\section{RECENT RAJA UTI TALES ON THE INTERNET}

As a source from which to compare these older stories with more recent Toba Batak storytelling, I have chosen an article containing stories recorded by the young Toba Batak journalist Norista Rosario Hutajulu, published on 5 October 2014 in Kompasiana, an Internet platform of the Newspaper Kompas for user-generated content. The journalist travelled to the Pusuk Buhit region, which is regarded as the region in which the Earth was created and where the ancestors of the Batak built their first villages, to visit sacred places and talk to storytellers. The result is an illustrated article consisting of five parts entitled: "The Legend of Pusuk Buhit and the Origin of Si Raja Batak" (Legenda Pusuk Buhit dan Asal Muasal Si Raja Batak). In the first part, The Legend of Pusuk Buhit, the author summarizes the story of the creation of the Earth derived from the most widely known source, the origin story published in Waldemar Hoetagaloeng's book entitled Poestaha taringot toe tarombo ni Bangso Batak, 'Pustaha (Book) on the subject of the genealogy of the Batak people' (1926, reprinted in 1991). In the second part, she provides some hypothetical historical information about the origin of Si Raja Batak, the founding father and eponym of the Batak people. The third, fourth and fifth parts contain stories about Raja Uti, which she recorded from local storytellers.

The article shows how very much alive the Raja Uti stories still are. Actually, the text presented here is just a small excerpt from a vast complex

23 This part of the text is somewhat difficult to interpret. Has the High God created a husband for Dayang Parujar by merging a tiger and a crocodile? Both animals are regarded as sacred ancestors in many parts of Sumatra. It might be an attempt by the storyteller to give an explanation of how this ancestor-ship has came about. 
of stories, which are told from different perspectives in different places. More than any other Toba Batak story, the tales of Raja Uti are linked to a sacred geography, which includes many places in Sumatra, both in- and outside the land of the Toba Batak. A modern development in the past twenty years is that (at least) two Raja Uti temples or monuments have been built, one on the slopes of Mount Pusuk Buhit; the second in the Barus area (see Illustration 4).

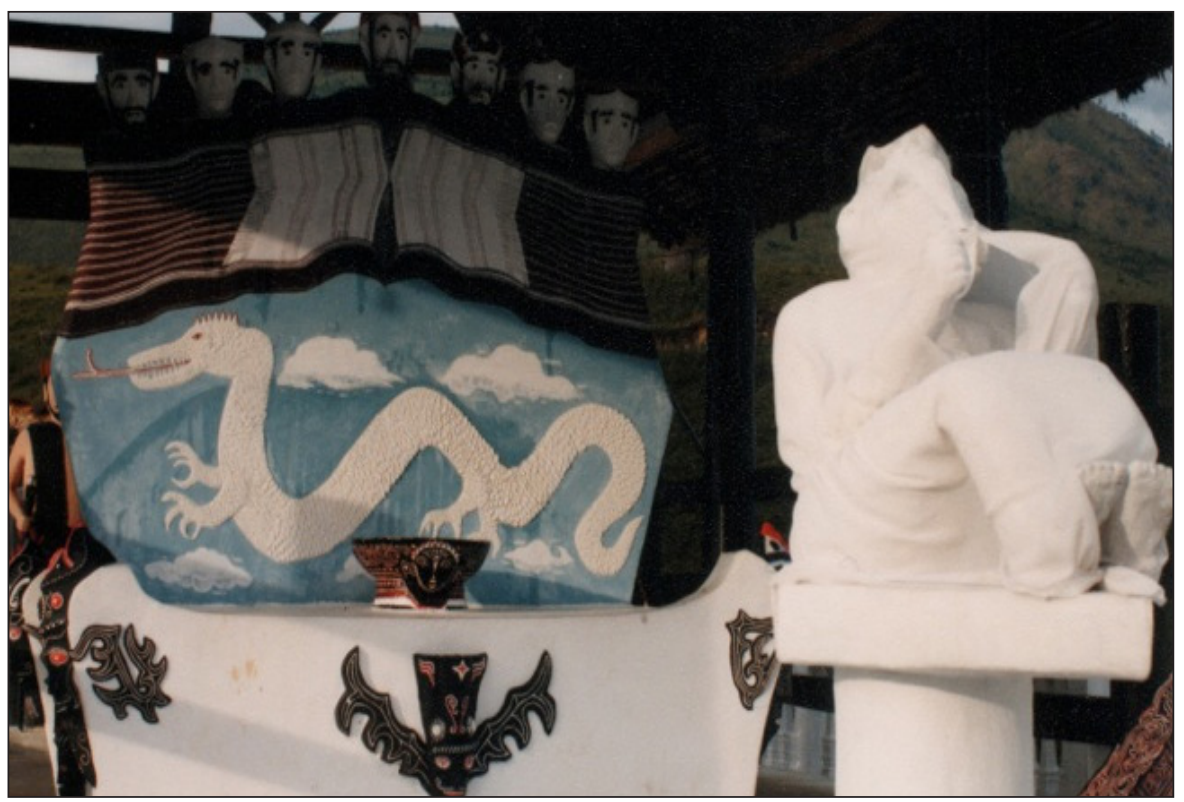

Illustration 4. Two forms of Raja Uti. On the right, covered with white cloth, the shape of the human body with the head of a pig form and on the left the dragon form. The seven heads in the background represent other forms from different stories (photograph taken at the Raja Uti Monument or Temple (Tugu Raja Uti) on the slopes of Mount Pusuk Buhit, Sianjur Mulamula district, by the author, 1996).

Essentially the stories relate the passion of Raja Uti: how he (or she or it) ${ }^{24}$ was born as an incomplete (in the text cacat, literally: handicapped) human being (without arms, legs, and bones); how he suffered from the envy of his brothers and sisters who even tried to kill him on various occasions and how he was transformed from a hated, helpless being into the ultimate source of sacredness, blessing and power. Raja Uti, born to a heavenly mother ${ }^{25}$ and an earthly father (Guru Tatea Bulan, ancestor of the elder Toba Batak moiety), was first called Raja Gumelenggeleng (the one who could only roll over), and

24 In this story Raja Uti is described as male. I was told by Ama Juang Naibaho, a learned datu and specialist in the Pusuk Buhit mythology, that Raja Uti was also female. The androgyny of Raja Uti is also confirmed in older texts (see below). In one version Raja Uti has a twin sister who was born with the same physical characteristics (see Ypes 1932: 187-188).

25 The only information this story provides is that she was one of seven heavenly nymphs (gadis dari kayangan) sent down by Mulajadi Nabolon or Tuhan Yang Maha Esa. In an older version, related by the Jonggi Manaor (who is regarded as one of the sacral kings) and recorded by Ypes (1932: 187), Raja Uti's mother was Boru Deak Parujar, the Creator of the Earth. 
later, when he was somewhat fatter, Raja Biakbiak (the fat one). In time he would accumulate many more names.

His mother hid him in a cave and fed him there for a while but, when his younger brothers found out, they again wanted him dead. Finally his parents took him to the top of Mount Pusuk Buhit where they abandoned him to the mercy of God. Many years later all the people in the village heard the voice of the High God: "Ei, manisia, gellengmi ndang mate" (Oh indeed, humans, my child is not dead). Thereafter Raja Uti appeared in different forms ${ }^{26}$ and under different names; Raja Uti is said to be his last name. He informed the people that they could only pray to Mulajadi Nabolon through him. Initially he demanded human sacrifices but, at the request of the villagers, the human sacrifice was replaced by a buffalo sacrifice. ${ }^{27}$ The journalists local informants also provided information about the type of sacrifice private pilgrims bring nowadays. The smallest sacrifice consists of seven lemons, seven betel leaves and seven eggs. If people can afford it, they sacrifice a chicken or a goat. The article maintains that even today powerful Indonesian politicians climb Mount Pusuk Buhit to make offerings to Raja Uti and ask for his blessings to assure their future successes.

Kini, melalui penguasa puncak Pusuk Buhit itu para peziarah memanjatkan doa kepada Mulajadi Nabolon, Sang Pencipta. Sudah bukan rahasia umum bahwa banyak orang, termasuk politikus parlemen dan pejabat pemerintah, menaiki puncak Gunung Pusuk Buhit dan menyembah Mulajadi Nabolon. Antara lain, kata anggota DPRD Kabupaten Samosir Tuaman Sagala kepada Koran Toba, "Mantan Gubernur Syamsul Arifin, mantan Menteri Pertanian Bungaran Saragih bersama istrinya yang orang Jepang itu sudah beberapa kali ke sana, Akbar Tandjung". Rekan sejawat Tuaman di DPRD Samosir, Jonni Sihotang, terangterangan mengakui rajin berdoa di puncak Pusuk Buhit, dan permintaannya selalu terkabul.
Nowadays, the pilgrims send their prayers to Mulajadi Nabolon, the Creator, through the ruler of Mount Pusuk Buhit. It is an open secret that many people, including parliamentarians and government officials, climb Mount Pusuk Buhit to worship Mulajadi Nabolon. Among these have been, as Tuaman Sagala, a member of the regional parliament of the district of Samosir, told the newspaper Koran Toba: "The former governor Syamsul Arifin, the former Minister of Agriculture Bungaran Saragih and his Japanese wife, (and) Akbar Tanjung (former chairman of the Golkar faction)". His colleague in the Samosir parliament, Jonni Sihotang, openly confesses that he often prays on top of Mount Pusuk Buhit, and his petitions have always been granted.

26 His best-known form is a human body with the head of a pig, which, however, is not mentioned by Hutajulu. However, this form is depicted in a statue in the Raja Uti temple in Sianjurmulamula which she visited.

27 I also encountered stories about human sacrifice in Sihotang; see Angerler (2009: 227-230); compare also Ködding (1885: 478). 
Penganut agama-agama mutakhir, khususnya agama langit seperti Kristen dan Islam, mungkin akan sangat sulit menerima keberadaan Mulajadi Nabolon dan "nabi"-Nya di Tanah Batak, Raja Uti.
For followers of modern religions, especially heaven-(oriented) religions like Christianity and Islam, the existence of Mulajadi Nabolon and his "prophet" in the Batak lands, Raja Uti, might possibly be very difficult to accept.

However, where is the proof that Raja Uti is the High God? The text in Kompasiana speaks of Mulajadi Nabolon and his prophet (nabi) Raja Uti and does not claim that Raja Uti is God. It merely states that he is a messenger of God. Or, is he, as the High God Mulajadi Nabolon is quoted saying (in the only sentence in Toba Batak language), gellengmi ('my child'), in this context the "child" of God?

The truth is that only Batak shamans and mystics ${ }^{28}$ seem to be really acquainted with the mystery and the Divinity of Raja Uti, who never dies and never grows old (na so ra mate, na so ra matua) ${ }^{29}$ and this mystery was certainly not revealed to the journalist. Nevertheless, it might still be possible to find some answers by returning to the older texts.

\section{RAJA PINANGKABO AND THE REINCARNATION OF THE HIGH GOD}

More information about the idea of the manifestations of God is found in a story which narrates how the High God, Tuan Bubi na Bolon, debata ${ }^{30}$ na sadasada I ('the only God'), initiates the Creation and is subsequently reborn or reincarnated as Raja Pinangkabo. This text was recorded by Guru Ruben and collected by the missionary physician and Batakologist Johannes Winkler (probably around 1910 in the Toba or Humbang region). The original manuscript has been lost. Winkler, who had not prepared any copy of the manuscript, lent it to the PhD student Philip Lumban Tobing, who took it to Indonesia after he had obtained his doctorate in Utrecht 1956, and it has been missing ever since. Earlier a translation of the text made by Winkler had been lent to Petrus Voorhoeve to aid him in the preparation of his $\mathrm{PhD}$ (see Voorhoeve 1927). Voorhoeve returned the translation to Winkler without making a copy. The translation was also lent to Philip Lumban Tobing and is now also missing. Therefore all we know about this important text comes from the extensive quotations in Philip Lumban Tobing's PhD thesis (Tobing 1956). I should add that, in the following translations of the quotations, I have not always followed Tobing's translation.

The text opens with the beginning of the creation (see for the following seven quotations from Guru Ruben's text Tobing 1956: 30-36):

28 The Archbishop of Medan, Anicetus Bongsu Sinaga, also seems to fall into this category. He sees several aspects of Divinity in Raja Uti (2007: 72-74).

29 This attribute is mentioned in almost any invocation and prayer to Raja Uti.

30 Debata (of Sanskrit origin) is considered the general Toba Batak word for "God" and is used in this sense in church liturgy. For the wide semantic range attached to debata or dibata see Angerler (1997: 421). 
Adong ma na saingan, na saingan ni na robi, na margoar Ompunta Tuan Bubi na Bolon, i ma Debata na sasada i, na mangunsande di hau Singakammabarbar.

In the very beginning there was our Ompung ${ }^{31}$ Tuan Bubi na Bolon, the Only God, who leant against the Singkammabarbar tree.

Five times decaying matter fell down from the tree and this brought into existence all the animals of the water, the dry land, the forest; all domestic animals and all birds.

Dung i margoar ma tolu pidong $i$ dibahen Tuan Bubi na Bolon, saasta ganjangna, tolu dopa liliton bolonna, i ma na mangunsande di hau Singkammarbarbar $i$, na manggoargoar pidong si tolutolu $i$;

na sada marbaringbing, i ma na margoar pidong pidong Patiaradja, ia na sada ganjang imputna, pidong Maoang-maoing ma goarna, alai anggo na sada nari, ndang malo habang, ndang malo mardalan, pidong Mandoangmandoing ma goarna.
And then he gave names to three of the birds, Tuan Bubi na Bolon, who is one cubit or ell in height and whose circumference is three fathoms, who leans against the Singkammabarbar tree, named the three birds;

the (first) one with the crest was named Patiaradja, the (second) one with the long feathers was given the name Maoangmaoing, but the [third] one, which could neither fly nor walk, was called Mandoangmandoing.

We do not have the original Batak text for the next section, only the summary provided by Tobing:

The bird, Patiaradja, took the bird, Mandoangmandoing, to wife. The latter got five young ones, of which four were still in the eggshell. The fifth was a monster, with the snout of a pig, a human body, hair like that of a cow, the tail of a kerbau, the mane of a horse, the ears of a goat and a belly like that of a hen. In great astonishment the bird, Patiaradja, went to the bird, Maoangmaoing, whom he told what has happened. As a matter of fact, the bird, Maoangmaoing, already knew, for he was a bird that knew the future and the past. He gave the bird, Patiaradja, the following advice: ${ }^{32}$

Olo anggo i do, so tung didok ho i anakmu, na so tandap baoa $i$, dohot borum na so tandap boruboru $i$.

As to what has happened, you must never call it (the "monster") ${ }^{33}$ your son because it is apparently not male, nor your daughter because it is apparently not female.

Furthermore, the bird Patiaradja is advised on the proper use of terms of address in Batak society, and is told where to put the unhatched eggs and the "monster":

31 Grandfather/grandmother, ancestor and respectful term of address.

32 Tobing 1956: 32.

33 We do not know how the being Tobing calls "monster" was actually referred to in the original text when it was introduced the first time. In the parts of the text quoted, it is referred to as ibana or $-n a$, the third person singular, which does not indicate gender in Toba Batak language. 
Alai anggo na opat dongan na tubu $i$ peakhon ma tu garaga julu, alai bahen ma ingananna ragaraga na bolak, tantan ma ibana sian toding banua ginjang, sian singkam na ruangon, tu jait golangolang, tu toding banua tonga an, di toru ni langit ni langitan, di atas ni laut na bidang. Disi ma ibana manggunanggun, dipaullullus angin, dipaombusombus alogo.
The four birth companions (in the eggs) should be put on a potsherd close to the hearth, but for it (the "monster"), you must make a ragaraga, a large square rack, and suspend it from the Upperworld, from the hollow singkam tree to which it is fastened by a brass chain, towards the Middleworld, under the heavens, above the wide sea. There it will be rocked, moved by the wind, swung to and fro by the storm.

And it should be addressed in this manner (list of names and attributes):

Raja Pinangkabo, Raja Pinangkabua, na so olo mate, na so olo matua, Tuan Bumi na Bolon, Raja tonggam di langit, Mulajadi na Bolon na hundul di banua holing, na mangunsande di batu barani, na dumompakhon bilang na uli, na tumundalhon bilang na so magabe.
Raja Pinangkabo, Raja Pinangkabua, he who neither dies nor grows old; Tuan Bumi na bolon, the majestic Raja of the Upperworld, Mulajadi na Bolon, who lives (literally: sits) in the region of the lightning, who leans against the very hard stone, who turns his face upon good fortune, but turns his back upon bad luck.

This is followed by instructions on the type of sacrifice to be made to Raja Pinangkabo and under which circumstances this should be offered:

Ba molo munsung dipatuduhon tu ho, pasahat ma tu ibanababi simenengeneng, asa marbunga emem, asa marboras gadongmu; alai molo dengdengna dipatuduhon tu ho, pasahat ma tu ibana manuk lahibini, unang adong sapata tu ho. Alai anggo pinggolna do dipatuduhon, pasahat ma tu ibana hambing puti, unang adong na huliton; alai molo jambutna dipatuduhon tu ho, pasahat tu ibana hoda na bara, unang adong haleon potir. Ia dipatuduhon ihurna, pasahat ma tu ibana horbo pangalotlot, unang adong tahi ni halak dohot tahi ni begu abar.
If he shows his snout, offer him a fat pig as sacrifice, so that your rice may thrive and your tubers may flourish; if he shows his belly, give him a red and a white hen, so that no curse might come upon you. However, if he shows his ear, sacrifice a white goat to him, so that there will be no lepers. If he shows his mane, sacrifice a chestnut horse to him, so that there shall be no famine. If he shows his tail, kill a pangalotlot buffalo (literally: a trampling buffalo) for him, so that there will be no wicked plans made by evildoers and roaming spirits. 
Alai molo imbuluna dipatuduhon tu ho, pasahat ma tu ibana lombu sitiotio, unang adong na golap. Ia dagingna dipatuduhon tu ho, pasahat ma tu ibana horbo bus, asa horas hamu saluhut, i ma na gabe hasomalan tu joloan on pasahaton ni jolma manisia.
But if he shows his feathers, you must sacrifice a sitiotio cow (a cow which brings clarity) to him, so that all will be well. And if he shows his whole body, you must sacrifice a bius buffalo to him, so that you all may be healthy and well. In the future this will become the custom among men.

After these instructions, an earthquake caused the four eggs to burst open. Out of the eggs came four beings in human form who took Raja Pinangkabo's place. He asked them why they had done so and they answered him:

“Ua apala na manoluk hami, Ompung!"
"Antong, molo songon i, boasa Ompungmu
ahu dohononmu?", ninna Raja Pinangkabo.
"Ala ho do na sangap, na badia, na tangkang
nanjuara. Asa i do alana, umbahen Ompung
ho hudok(hami)", ninna na opat $i$.

"Ai jinou ni sahalam do hami, ti(no)ngos ni hasangaponmu; ai na disampathon galumbang do hami tuson, diboan simaranginangin". Dung i manungkun ma Raja Pinangkabo: "Ai na sian dia do amam dohot inam, umbahen Ompum ahu dohononmu? Ai so manang tubu ni anakku manang borungku ho". Alus ni na opat $i$ : "Ai tubum hami hami Ompung, aut baoa ho, amang do dohonon nami tu ho; ia boruboru ho, inang do dohononnami; ai na sangap do ho, na badia, na tangkang, nanjuara, umbahen Ompung ho hudok hami".
"We have not taken your place, Grandfather (Ompung)!"Raja Pinangkabo said: "If this is so, why do you call me your Ompung?" The four replied: "Because you are the Mighty One and the Holy One, who can attain through his will, who is peerless. This is the reason we call you Ompung.

For your sahala ${ }^{34}$ has called and your power has summoned us; for the waves have tossed us to you, driven by the wind". And Raja Pinangkabo asked: "Where do you come from?" and they replied: "We do not know". "If so, who are your parents that you call me your Ompung? For you are not the sons of my son or of my daughter". The four replied: "If we were your own children, oh Ompung, then we would have called you father, if you were a man; mother, if you were a woman; for you are the Mighty One, the Holy One, whose will shall be done, you are peerless. This is why we call you Ompung.

Subsequently Raja Pinangkabo accepts his role and continues the creation by bringing up the human beings hatched from the eggs. He addresses them as grandchildren (pahompu), and assigns them names and positions. They are the Gods (debata) of the Upperworld, Batara Guru, Sorimangaraja, Mangalabulan, and Asiasi.

34 In this case, the term sahala denotes a hierarchical relationship on soul level between Raja Pinangkabo and the others. For an analysis of the complex concept of sahala see Angerler (2009: 378-396). 
In conclusion, the text recounts how the reincarnation of the High God came about. The reincarnated High God, whose form is a mixture of human and animal elements, is neither male nor female. Like that of Raja Uti, his snout is that of a pig and one of his attributes, which he also shares with Raja Uti, is that he "neither dies nor grows old". He has several names, and one of these is Mulajadi Nabolon. After hatching from the egg, the High God is not immediately aware of his position. He has to be given an explanation before he resumes his creative task among his Creation. He gives the newborn Gods names and allocates them their positions and future tasks. Moreover, he is there as a recipient of offerings and sacrifices from the human beings to secure fertility, safety, health and wellbeing (which can also be in a social sense). Even though this story takes place in primordial times and in the Upperworld, the human world is already anticipated. It is no coincidence that Raja Pinangkabo is put on the ragaraga, the suspended square rack. Accompanying the text of the story is a note by Guru Ruben, which explains the ragaraga:

This rack is suspended from the third crossbeam of the place of sacrifice. On it they place a dish for the sacrificial food and a pot "guriguri sidjonggi", containing the oil of Silaon na Bolon (Tobing 1956: 33, footnote 22).

Tobing regards Silaon na Bolon, who also encompasses both sexes, as a "manifestation of the High God" (1956: 66). Another story recorded by Tobing, which was told by Guru Silalahi from Tomok, Samosir, explains that on one occasion Mulajadi Nabolon had transformed himself into Silaon na Bolon (1956: 66-70), who is present in the miak (oil) siguriguri. ${ }^{35}$

This information opens up the possibility that the High God could also be present in the miak, the "fluid of life" which is kept on the ragaraga, suspended from the roofs in the sacred houses of the localized lineages (ruma parsantian in the Samosir region). This would explain why Archbishop Sinaga equates the ragaraga with the Roman Catholic concept of the tabernacle, in which God Christ is "truly present, Body and Blood, Soul and Divinity", enshrined in the presence of bread and wine.

35 This oil (miak) is a spiritual fluid. Miak siguriguri denotes both the content and the special container (guriguri), a kind of ceramic pot (guriguri sijonggi is a bigger version). In ritual practice, this oil is sometimes used to remedy female barrenness and is, as Tobing relates, "said to be liquor amnii" (1956: 70-71) or amniotic fluid. Parmiahan, literally "oil-container", is a polite way of referring to the womb. In prayers, miak is often equated with aek partondion, literally "water of fate" or alternatively "water of life" (For an analysis of the concepts of miak and aek partondion and quotations of relevant prayers [tonggotonggo] see Angerler 2009: 219-221). Guru Sinangga's stories (1872; MS Cod. Or. 1260z) recount that Sibaso na Bolon, the archetypal female shaman and midwife, created the miak (Sibaso na Bolon na jumadihon miak). Sibaso na Bolon is sometimes used interchangeably with Silaon na Bolon. 
Ragaraga gabe Tabernakel. Ragaraga The ragaraga becomes the tabernacle. na gantung di pamoltok ni ruma do The ragaraga which hangs from the inganan parmaebatan ni hadebataon laho third crossbeam of the house is the mangantoi jolma. Disi do muse dipatupa place where the Divineness comes to miak hangoluan ni Batak, gabe guriguri visit and to take care of mankind. It sijonggi (Sinaga 1997: 9). also is there that the fluid of life of the Batak people, the guriguri sijonggi, is presented.

\section{RAJA PINDANGKABO AND RAJA UTI ARE IDENTICAL}

The list of names and attributes given by Guru Sinangga (1872) reveals that he thought Raja Uti and Raja Pinangkabo were identical. As a spiritual insider, Guru Sinangga was aware that the many different stories did in fact refer not to separate deities but to different manifestations of God. This is made explicit in the following list of names and attributes of Raja Uti which occurs in the corpus of texts written by Guru Sinangga in 1872 (MS Cod. Or. 1260z). The context of the list is a story about the people of Silindung worshipping the ruler of Barus as the representative of Raja Uti, the source of the fertility of their land, by annually bringing him a black horse with white flanks. Historically, these horse-offering pilgrimages from Silindung to Barus took place until the year 1927.

Asa i ma hite ni hoda sisandang dera bahen somba tu rajanta (Now let us worship our raja by bringing him a black horse with white flanks):

Raja Barus (Raja of Barus),

Raja Jujur (Raja Of Accounting ),

Raja Miok (Raja Who Can Only Turn Around),

Raja Bangkit (Raja Who Is Exalted),

Raja Hatorusan (Raja Who Sees Through Everything)

Raja Babi (Raja Pig [-head])

Raja Uti (Raja Possessed of Superhuman Abilities)

Raja Pinanghabo (Raja of Minangkabau?)

Raja Ulu ni Ubi (Raja with the Head of a Tuber)

Raja na so ra mate, raja na so ra matua (Immortal Raja, Raja Who Never Grows Old), na matua dolidoli sipeop pusuk bujur (the Holy Bachelor, Keeper of the Horizontal Tree Top), na martotoran tarugi (the One Who Uses a Rib of the Sugar Palm Frond as a Lance-shaft), sipeop ri na so ra malos (Keeper of the Alang-alang Grass (Imperata cylindrica) Which Never Withers)

Every name Guru Sinangga lists here refers to a different story and to a different aspect of Raja Uti. Every one of them can be understood as a different image and a different manifestation of God. 
TRYING TO UNDERSTAND TOBA BATAK STORIES ABOUT THE HIGH GOD

Toba Batak storytelling can be likened to their traditional way of life in precolonial times. Although there was no state or any form of central government, there were laws, social structures and a host of rules to regulate many aspects of life. However, despite the many regulations, a significant amount of individual freedom was still allowed. This individual freedom also extended to Toba Batak storytelling, especially in the recounting of sacred stories. Despite the existence of set themes and basic ideas and a set of structural rules to be followed, any trace of dogmatism is absent. The storytellers have always had a degree of freedom to give their stories different twists and to invoke images conceived in their own imagination - even when these have to do with God.

Almost all the stories discussed in this paper invoke an image of God, which says something about His, Her or Its form, and the storytellers ascribe attributes drawn from, often long, lists of such appellations. The gender of the High God is not fixed. It can be female (inang Silabi Mulajadi), both male and female (отри boru ompu doli Mula Haranna, Raja Uti), neither male nor female (na so tandap baoa, na so tandap boruboru, Raja Pinangkabo), abstract or no gender is specifically mentioned (Mulajadi Nabolon in Guru Sinangga's origin story, and as perceived by some of the people) or male (present-day Raja Uti and Mulajadi Nabolon as perceived by another group of the people).

The High God has been said to have a form impossible to describe (Tuan Bubi na Bolon), or to have that of a river turtle (Silabi Mulajadi), a dragon (Mula Haranna) or a giant serpent (Baganding Tua). His/Her form might be a combination of various animal and human parts (Raja Pinangkabo), perhaps with a human body and the head or snout of a pig (Raja Uti) or as an incomplete, not fully formed human (the young Raja Uti and Boru Milingiling). Mulajadi Nabolon's form is not mentioned, or he might be described as a male human being. ${ }^{36}$ Furthermore, the High God can be also thought to be present in the spiritual fluid miak (Silaon na Bolon, Sibaso na Bolon).

In our stories the High God can reside in various places and is not confined to the seventh layer of the Upperworld (Mulajadi Nabolon) or simply in the Upperworld (Silabi Mulajadi), but might also be in the Underworld (Mula Haranna), in the sea or in Lake Toba, on a rack suspended between the Upperand the Underworld (Raja Pinangkabo) or, by analogy, on a rack suspended from the third crossbeam of the roof of the ruma parsantian, the sacred house of the localized lineage (Silaon na Bolon, Sibaso na Bolon). The High God can also reside on the top of Mount Pusuk Buhit (Raja Uti), in a cave (Si Raja Biakbiak, the young Raja Uti and his twin sister, Boru Milingiling), in the jungle (Baganding Tua, Raja Uti), on an uninhabited island (Raja Uti) or even

36 We do come across stories about Mulajadi Nabolon descending to Earth and behaving in a human fashion recorded as early as the nineteen-twenties and -thirties, see Ypes (1932: 187); Mangaradja Salomo Pasariboe (1925: 27-31, 1938: 21-22). In the course of my research, I heard - in an urban context - various stories describing Mulajadi Nabolon as a human being and even as the very first ancestor of the Batak people. 
in foreign countries (Minangkabau, Barus, Aceh, Riau: Raja Pinangkabo, Raja Uti).

Most stories about the High God betray some tangible outside influence. In one way or another imagery and terminology and concepts have been affected by religious ideas from outside and by an internal-Batak discourse. As far as I have been able to observe, external influences are not a new phenomenon, possibly because many Batak storytellers were learned shamans $(\text { dat } u)^{37}$ who have always had a reputation for being open to new information and eager to expand their knowledge. Early missionary accounts remark that it was much easier to explain the concepts of Christianity to shamans than to ordinary people $^{38}$ as the former could grasp these more readily than people who had not enjoyed the formers' intellectual training. Cogently, although Toba Batak shamans were far from reluctant to learn about and take new concepts on board, they usually seem to have wanted to incorporate their newly acquired knowledge into their own framework. An interesting example is the shaman Guru Somalaing Pardede, who learned about Roman Catholicism from the Italian explorer Elio Modigliani and subsequently, during an early stage of colonialism, incorporated Roman Catholic and Protestant terminology into a genuine Batak framework in his endeavour to found the anti-colonial millenarian movement, which is regarded as the initial formation of the religious community of the present-day Parmalim. ${ }^{39}$

Raja Mulia Naipospos, the founder of the successful Parmalim organization Hutatinggi, shows that the process might also work in reverse. After being trained as a teacher by the Rhenish Missionary Society, he incorporated Toba Batak religious terminology and ritual into the framework of monotheism - both Christianity and Islam. Another way of preserving traditional Toba Batak spirituality, to some extent at least, is revealed in the work of the present Archbishop of Medan, Anicetus Bongsu Sinaga, the son of a shaman. Keeping within the framework of the Roman Catholic "enculturation" endeavour (inkulturasi), in his stories he maintains that the traditional Batak religion is in fact a precursor of Roman Catholicism (1997, 2007). Converts to Catholicism should not "break" with the old religion (as the Protestant proselytes are required to do) but simply continue their spiritual journey within the Roman Catholic context. ${ }^{40}$

37 Probably the best description and analysis of the education, tasks and working methods of the Toba Batak datu was written by Kenan Hutabarat 1925; see also Winkler 1925; Bartlett 1973.

38 I remember reading this several times during my research in the archives of the VEM, Wuppertal, but I cannot provide the exact quotation.

$39 \quad$ See De Boer (1914: 381-385); Masashi Hirosue (1988: 75-125), and for a critical assessment Angerler (1995: 136-138); for a picture of Guru Somalaing see Modigliani (1892: 87).

40 It is very interesting that Sinaga has the freedom to tell his spiritual Batak stories and even to lead buffalo sacrifice rituals (compare: https://www.youtube.com/ watch? $\mathrm{v}=5 \mathrm{~d} 2 \mathrm{CH} 088 \mathrm{QL} 0$ ) and at the same time remain firmly rooted in one of the most dogmatic religious organizations of the world, the Roman Catholic Church. Toba Batak with a Protestant background who wished to preserve the spiritual roots of their people with their stories had to go their own way, as the case of Raja Patik Tampubolon shows. Tampubolon (1964) wrote 
A similar construction also seems to have been at work in pre-colonial times. Unfettered by requirements to adhere to any kind of religious dogma, the minds of shamans and storytellers remained open to new spiritual information. The upshot is that every story presented here has one way or another been influenced (or enriched) by information acquired from outside.

As Harry Parkin discusses in his PhD thesis "Batak fruit of Hindu thought" (Parkin 1978), Hindu influence in concept and terminology is omnipresent in Toba Batak religion. Certainly, in the first two stories discussed in this paper, it can be assumed that the names of the High God (inang Silabi Mulajadi and Mula Haranna) refer to the world-bearing turtle of Hindu mythology. Parkin, who has pointed out the predominance of Sivaite influence on Batak theogony, postulates that Mulajadi Nabolon can be viewed as "the Batakized version of Mahesvara" (an epithet of Shiva; Parkin 1978: 182). He also suggests that the debata na tolu, the three "human" Gods, Batara Guru, Soripada and Mangala Bulan, are "the Batak version, not of the Hindu trimurti of Brahma, Vishnu, and Shiva, (but) of the Shiva trinity" (page 182). They might also conceivably be seen to represent the three gunas or qualities of the primal material energy (prakriti): sattva, rajas, and tamas (Parkin 1978: 183-184). ${ }^{41}$

Returning to Guru Sinangga's story "Mula ni Jolma", two important points emerge. The first point is that it is possible to recognize the name of Sori Mahumat, the firstborn son of Batara Guru, as Islamic. The second point is the fact that Mulajadi Nabolon is described as the purposeful (and not accidental) Creator who assumes a much more abstract character in this story than even in later adaptations of his own text. The possible conclusion is that his story has been influenced by both Shivaism and by Islamic or/and Christian monotheistic ideas. But this should not distract from the fact that he is also telling a wonderful, original Toba Batak story. Guru Sinangga has made a personal synthesis which takes into account the spiritual influences of his time as well as the spiritual knowledge which he had inherited.

The stories about the manifestations of the High God on Earth fall into a different category. Such manifestations as Baganding Tua, Raja Uti or Raja Pinangkabo, which were of paramount importance to the people in precolonial times, have retained some degree of this real importance up to the present. As mentioned above, the principal community rituals were devoted to local manifestations of the High God. In the past this was the annual buffalo sacrifice of the bius community, a ritual in which everybody was expected to take part, because the wellbeing of the entire community and the position of every single member was at stake. Ritual buffalo sacrifices as an act of worship to the manifestation of the High God do still take place, but they are no longer a ritual in which the entire local community takes part. The Protestant churches,

Pustaha Tumbaga Holing, which can be considered as one of the most fascinating and also most honest endeavours to tell the story of traditional Batak spirituality.

${ }_{41}$ In the context of the discourse of the Toba Batak, this trinity can also be viewed as representing or symbolizing the main positions in the pre-colonial socio-political order of the Toba Batak; see Angerler (2009: 275-278). To the non-expert in Hindu religion, the three human Gods appear firmly rooted in Batak culture. 
for example, regard such ceremonies as vestiges of paganism and forbid their members to attend them. At present worship of the manifestation of the High God is often sponsored by money from outside the village (as are the temple buildings) and the group of worshippers is composed of both local villagers and urban Batak. The stories are kept alive by both groups: the villagers who hear and tell them and the urban people who write the stories down and publish them in books and articles.

Personally, although I have never encountered any particular religious fervour for Mulajadi Nabolon, who seems to be a figure of historical or cultural interest, I have witnessed immense fervour for particular manifestations of God in some parts of Batak society.

This discrepancy raises the question of the reasons which are prompting this lasting fervour for particular manifestations. It cannot be associated with ancestor worship, since these manifestations do not form part of the Batak genealogies. The stories make it abundantly clear that these manifestations are not human, or at least not completely human. Their forms can be many and various. Baganding Tua is a giant serpent. Raja Uti, who can assume different forms, is generally imagined as having either the head or at least the snout of a pig. Raja Pinangkabo is conceived as a combination of animal and human parts. All of them transcend gender as they transcend the spiritual or "hidden world" (portibi hahomi on) and the visible "light-" or "day-world" (portibi hasiangan) of humans.

Alongside the "spatial" order in the stories, which the tripartition of the world in the tales might resemble, in Toba Batak spiritual culture there is also the (lesser known) division into a "hidden" and a "visible" world. The "hidden world" encompasses and permeates the visible world of human beings. Contact between the two worlds can take place during dreams and during any trance of a shaman. ${ }^{42}$ The mouth of Baganding Tua (into which animals enter when they wish to die) is understood to be a gate into the hidden world inside the body of the High God, Baganding Tua, which constitutes both the realm of death and the source of life. The inside of the Deity is described as encompassing the visible world. Similarly, the unborn child inside the womb is still in the hidden world floating in the primordial sea (na di dalom laut; Van der Tuuk 1861: 461) before it is born into the light-world in which living humans have to dwell. ${ }^{43}$ As the source of life, the inside of the womb and its fluids (compare to the concept of miak described above) is an important metaphor used in giving a description of the spiritual world among spiritual insiders in Toba Batak culture.

42 See MS Or. 3402 p. 205 (manuscript by Guru Tinandangan from the collection Van der Tuuk) for a description of this relationship.

43 Several informants told me about this concept; the manuscript of Ompu Raja Bakti Sitorbandolok contains written information about it (MS D Or. 75921254 0). For my analysis of the mystery of portibi hahomion and portibi hasiangan see Angerler (2009: 166-168). 


\section{Indigenous roots in religious belief}

The manifestations of the High God have their place beyond the cultivated land, somewhere in the wilderness. They reside where no people live (the jungle, mountain tops, uninhabited islands). Since no Batak people used to live in foreign countries, they too could also have been classified as uncultivated. Although the ragaraga, the hanging rack in the ruma parsantian seems to contradict this idea, all the existing ruma parsantian I have found in my area of research have been uninhabited. As they are regarded as sacred, awe-inspiring places they are left empty.

From this point of view, as a category all these manifestations of the High God would represent the third, the "autochthonous source of blessing" in Reimar Schefold's theory of the "three sources of blessings in traditional Indonesian societies" (2001). In many cases these autochthonous sources of blessing in Indonesian tribal societies are supernatural beings associated with the wilderness or uncultivated nature (see also Schefold 2002). The other two sources of blessings are the ancestors and the wife-givers.

In Toba Batak society, ritual interaction with both ancestors and wife-givers is still unhindered by either state or church law and the flow of blessings from these sources remains assured. However, although once upon a time it was precisely this category of ritual interaction which used to be very important, ritual interaction with non-human nature or autochthonous spiritual beings is banned by church doctrine.

\section{The socio-political importance of the relationship with autochthonous spiritual beings}

In pre-colonial times, the ritual relationship with autochthonous spiritual beings was fundamental to socio-political relationships among the Toba Batak people. Hierarchies were not created by warfare but by activities related to foundations. The ritual act of founding (always performed before building a house, a village, a bius, an irrigation canal), a ritual of creation which was required to be performed by a group of at least three married couples, consisted of the forming of the buhit, to represent the primordial hill or mountain of Creation (with plants on top of it, representing the Tree of Creation), ${ }^{44}$ and the subsequent making of offerings to the original owners of the land, the autochthonous spiritual beings, to assure their approval of the project. The offerings had to be presented to the spirits by (married) women. This can be understood to have been a renewal of the original relationship with the autochthonous spiritual beings originally forged by Boru Deak Parujar, the female creator of the Earth and of culture. ${ }^{45}$ Importantly, the performance of this ritual was more than just to assure spiritual approval of and protection during the technical act of building something, it was in fact the foundation

44 For an analysis of the complex symbolism of buhit see Angerler (2009: 151-153, 203207, 256-257, 278-280, 426-430).

45 For this aspect of the relationship between myth and ritual see Angerler (2009: 257261). 
of a socio-political institution with an internal hierarchy, which would endure for generations (see Illustration 5). In pre-colonial times the relationship with the autochthonous spiritual beings also formed the basis for the socio-political acceptance of hierarchies, as the founders and their descendants were usually entitled to a leading position within the institution. ${ }^{46}$

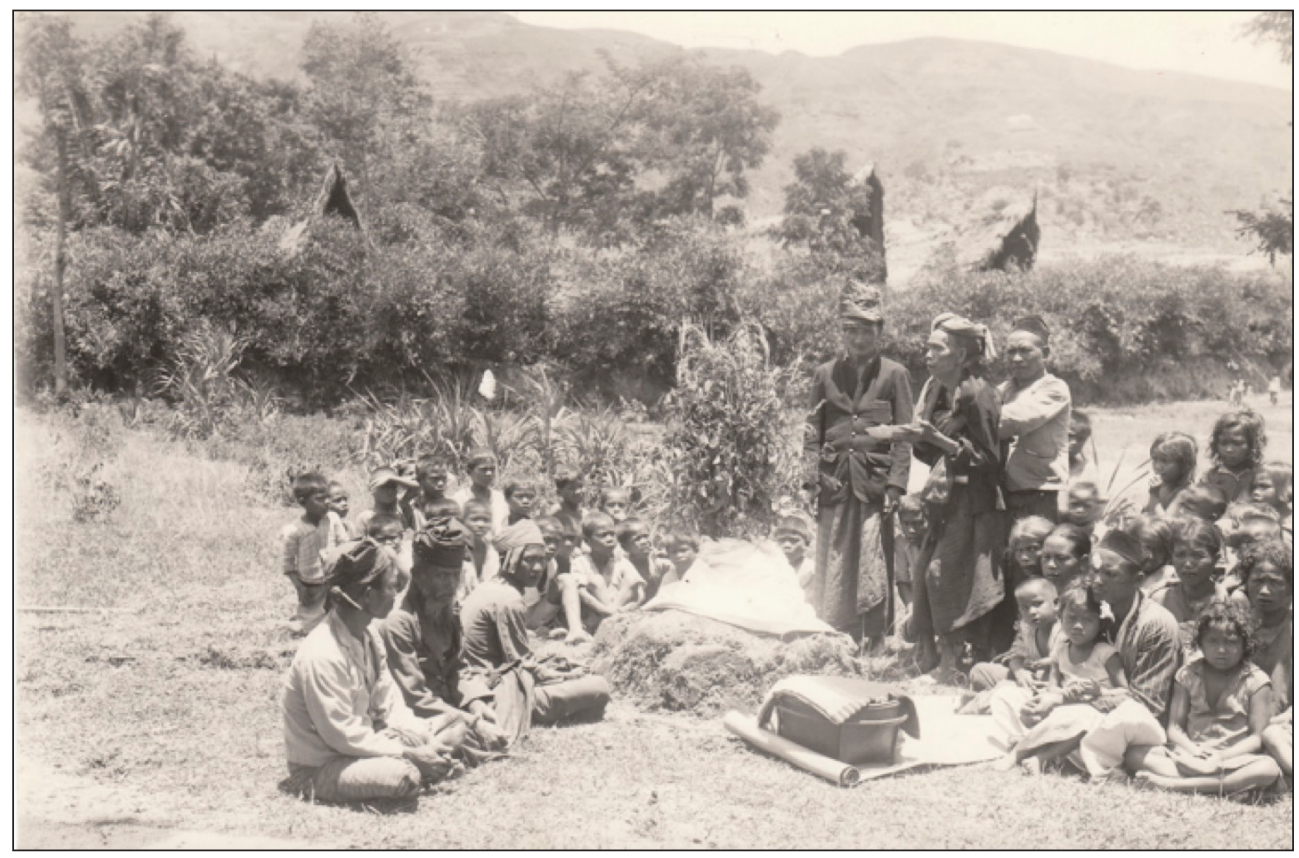

Illustration 5. Only known photograph of a village foundation ritual (martua omaoma) during colonial times. From the legacy of Johannes Winkler; courtesy of Ms. Helga Petersen. A lesser quality reproduction of this photograph was published in Tampoebolon 1935.

Who or what exactly are the autochthonous spiritual beings? The best way to provide a short answer is to give an example. ${ }^{47}$ In Sihotang people make offerings to several truly localized spiritual beings (who are not ancestors), nevertheless a relationship to the creation stories is also palpably present. The elder sister of Boru Deak Parujar (under the name of Boru na Mora and Boru Tindolok), who sank into the ground in the stories, is treated as an autochthonous spiritual being and a very important recipient of offerings. The principal autochthonous being of the region is Baganding Tua, the manifestation of the High God located in the largest patch of forest. All living beings are dependent on him. In pre-colonial times, the offerings to Baganding Tua, especially the annual buffalo sacrifice, reconfirmed the complete set of spiritual and socio-political relationships for the entire region.

46 For a more far-reaching analysis of the significance of founding rituals and the relationship with autochthonous spiritual beings see Angerler (2009: 423-435).

47 Answering this question in depth would lead me to another set of stories and data. See for more information on that subject Angerler 2009, Chapter 8. 
An examination of the stories reveals quite unequivocally that, in spite of some foreign influence, in most cases the Toba Batak High God is the ultimate autochthonous being, not the very first being but the first creative spiritual being, who is later reincarnated as part of the Creation, continuing to represent the blessings (and the potentially destructive forces) of uncultivated nature on which mankind depends.

\section{How should the "suffering God" Raja Uti be understood?}

The aspect of suffering is a very important part of the storytelling about Raja Uti. He is not just a mighty spiritual being or simply a manifestation of the High God. He was forced to undergo the experience of being born as an incomplete human being. As a completely powerless child, he was subject to immense suffering as he was exposed to the envy of his brothers and sisters who repeatedly tried to kill him. Whereas Baganding Tua - one of the names of Raja Uti - of Sihotang, a localized manifestation of the High God who is imagined as a motionless serpent, clearly represents the ultimate autochthonous being, the significance of Raja Uti's suffering has to be understood in a different context. To be able to reach this understanding, it is necessary to return to the origin-of-the-Earth-stories. In these the creation of the Earth is obviously not solely the work of the High God; it is carried out with the co-operation of a suffering woman. Virtually all origin-of-the-Earth-stories emphasize the anxiety and suffering felt by Boru Deak Parujar (or whatever name the female creator of the Earth happens to be) after she was cast out by her parents and expelled from her village of origin in the Upperworld. She found herself in the inhospitable environment of the Underworld and felt the pain of separation. ${ }^{48}$

Despite her troubles, the resilient Boru Deak Parujar was able to overcome her despair and the resistance of the powers in the Underworld partly by subduing and partly by entering into an agreement with them. Consequently she survived and created the Earth and thereafter founded human culture. Survival is also an important aspect of the Raja Uti stories. I have listened to Raja Uti stories on various occasions and I remember that each time the storyteller emphasized the part of the story in which the young Raja Uti survives against all the odds. In the Internet version of the story mentioned earlier, the survival aspect of Raja Uti is emphasized by the only sentence in Toba Batak language, citing the words of Mulajadi Nabolon: "Oh indeed, humans, my child is not dead!"

48 Here for an example the description of suffering from the Guru Sinangga version (in the translation by Niessen 1985: 39): Si Boru Deak Parujar cried incessantly throughout the day, throughout the night, slapped by the water, tossed by the waves of the sea, bitten by the great crab. One by one her tears fell, dripped like slime from the three stones, like gentle rain in the third month, she cried tears, like drops from a pinched gourd; she did not sleep at night, she did not sleep in the day, but sang her mourning song: Your fateful bearing of me, mother who bore me, Your fateful begetting of me, father who begot me, the broken lance shaft, mother, to the singkam tree riddled by insects, the rejected one who will never learn, who does not heed knowledge, who does not heed warnings. 
Perhaps the Raja Uti stories, which are rather difficult to fathom, can be understood at least partly from the context of creation stories. In essence, Raja Uti is Boru Deak Parujar's child, ${ }^{49}$ which makes him the first human being born on Earth (being the first also means being autochthonous and being a source of blessing). This is the circumstance which enables him to relate to human culture as well as to the world beyond. Nevertheless, Raja Uti is the archetype of the "suffering God". In a way his own were a repetition of his mother's sufferings. Both mother and son suffered immensely before they were able to succeed on a spectacular scale.

Attempts have been made to fit Raja Uti into Christian contexts, comparing him to Jesus, or to a Roman Catholic priest (because he is thought to be celibate) but, as far as I have been able to discover so far, the Raja Uti stories still seem to me genuinely Batak. The motif of the boneless suffering God or suffering hero was already present before the knowledge of Christianity spread. ${ }^{50}$

This postulation is supported by the knowledge that suffering and the psychological and spiritual integration of suffering is an essential part of Batak life. A girl reluctant to marry her family's choice will certainly suffer, whether she actually marries or not, and so does a handicapped person (I have heard people portray the young Raja Uti as a handicapped person). Batak people are familiar with many ways of suffering and cogently in modern pop music they usually prefer songs about suffering to happy songs. The art of composing sad songs and describing suffering in beautiful laments is a very old tradition in various Batak languages.$^{51} \mathrm{~A}$ God who knows about suffering, knows about people. This is what might be felt by many who still worship Raja Uti, or perhaps they just enjoy listening to stories about him.

49 This story comes from an authoritative source, from Panaor, since pre-colonial and during early colonial times bearer of the title "Jonggi Manaor", who is regarded as one of the sacral kings of the Toba Batak; see Ypes 1932: 187. He tells the story of Boru Deak Parujar, her husband Guru Tatea Bulan and their two first-born children Si Raja Biakbiak and his twin-sister Boru Milinggiling. The story of their suffering and subsequent elevation is the explanation of the origin of the bius Buffalo sacrifice ritual. The motherhood of Boru Deak Parujar seemed unlikely to Ypes but, in mythological/spiritual terms, it makes perfect sense. In many versions of the origin myth, Guru Tatea Bulan, also often called Guru Tantan Debata by the local people, is Boru Deak Parujar's husband (for example, in Guru Sinangga's "Origin of the household" [Mula ni Parumaon], in which Guru or Datu Tantan Debata is also her brother; see Angerler 2009: 256, 284 footnote 1014. The name Guru Tatea Bulan also refers to the moon (bulan), the final place of residence of Boru Deak Parujar.

50 Compare the Dairi story about Si Mbuyak-Mbuyak from the collection Van der Tuuk (Brakel-Papenhuijzen 2014: 112-127). This story also belongs to the Raja Uti/Raja Pinangkabo story-complex. The hero (not God) of the story is born boneless and his suffering is exacerbated because his family is in debt. Later he cures his condition and becomes able to communicate with the trees. Because of this ability, he can easily locate camphor and so helps his family out of debt. Later he goes to Aceh, marries a princess and founds his own settlement. People call him Raja Pinangkabo and it is said that he never dies. The story ends with the sentence: "It is a story of the old people that I have written, that I have told" (page 126).

51 See Kozok 1994, for Toba Batak and Karo traditions, and Brakel-Papenhuijzen 2014, for Dairi storytelling. The hata andung, expressing grief and suffering in special words, is more than just a mourning language, as it is also used to speak in an extremely polite way to persons and spiritual beings one wants to honour (see Marcks 1930). 
However, the aspect of suffering does not explain all the stories about manifestations of the High God, not even all the stories about Raja Uti. There is much more to traditional Toba Batak spirituality.

\section{EPILOGUE}

I hope to have shed some light on the relationship of Toba Batak People with their High God, and to have communicated my fascination with Batak stories. They keep fascinating me; even though they somehow seem to resist a completely satisfactory interpretation. Some mystery always remains. I am relieved to say that Toba Batak scholars also find these stories difficult to interpret. However hard we try to gain a better understanding of the mysteries they contain, new questions keep emerging. I have no difficulty in imagining the immense pleasure the old masters of storytelling must have felt when they were telling their stories to an audience.

\section{REFERENCES}

\section{MANUSCRIPT SOURCES}

Koninklijk Instituut voor Taal-, Land- en Volkenkunde (KITLV/Royal

Netherlands Institute of Southeast Asian and Caribbean Studies)

MS D Or. 759212540 (Ompu Raja Bakti Sihotang Sitorbandolok)

Leiden Universiteitsbibliotheek (Leiden University Library)

MS Cod. Or. 1260z (Manuscripts by Guru Sinangga)

MS Or. 3401 (Nang Gorga di Portibi; handwritten copy by van der Tuuk)

MS Or. 3402 (Manuscripts by Guru Tinandangan from Naipospos; collection Van der Tuuk)

MS Or. 3421 (Boru Dayang Parujar and Mula Haranna; handwritten copy by Van der Tuuk)

MS Or. 3454 (Boru Dayang Parujar and Dayang na Gurasta)

Rijksmuseum voor Volkenkunde (National Museum of Ethnology) Leiden REM Nr. 129/267 (Boru Dayang Parujar and Mula Haranna; original pustaha)

Staatsbibliothek Berlin

MS Or. 13979 (Naga Situllang Bosi; original pustaha)

\section{Publications}

Angerler, Hans (=Johann). 1993. “Mission, Kolonialismus und Missionierte; Über die deutsche Batakmission in Sumatra", Beiträge zur Historischen Sozialkunde 23/2: 53-61.

Angerler, Johann. 1995. "[Book review:] Masashi Hirosue, Prophets and followers in Batak millenarian responses to the colonial order; Parmalim, Na Siak Bagi and Parhudamdam, 1890-1930. PhD thesis, Australian National University, Canberra, 1988", Bijdragen tot de Taal-, Land-en Volkenkunde 151: 136-138. 
Angerler, Johann. 1997. "Horas; Aspekte religiös-erotischer Symbolik der Batak, Nordsumatra", Anthropos 92: 409-431.

Angerler, Johann. 2009. Bius, parbaringin und paniaran; Über Demokratie und Religion bei den Tobabatak Nordsumatras. PhD thesis, Leiden University. [Ethnosystems and Development Studies (LEAD) No. 4.]

Bartlett, Harly Harris, 1973. The labors of the Datoe and other essays on the Bataks of Asahan (North Sumatra). An Arbor, MI: University of Michigan.

Bezemer, T.J. 1904. Volksdichtung aus Indonesien; Sagen, Tierfabeln und Märchen. Den Haag: Martinus Nijhoff.

Boer, D.W.N. de. 1914. “De Permalimsekten van Oeloean, Toba en Habinsaran”, Tijdschrift voor het Binnenlandsch Bestuur 47: 378-393.

Boer, D.W.N. de. 1915. “De Permalimsekten van Oeloean, Toba en Habinsaran”, Tijdschrift voor het Binnenlandsch Bestuur 48: 184-206.

Brakel-Papenhuijzen, Clara. 2014. Dairi and Pakpak storytelling; A storytelling tradition from the North Sumatran Rainforest. Leiden: Brill.

Brenner, Joachim Freiherr von. 1894. Besuch bei den Kannibalen Sumatras; Erste Durchquerung der unabhängigen Batak-Lande. Würzburg: Leo Woerl k.k. Hofbuchhandlung.

Groeneboer, Kees. 2002. Een vorst onder de taalgeleerden; Herman Neubronner van der Tuuk, taalafgevaardigde voor Nederlandsch Indië van het Nederlandsch Bijbelgenootschap 1847-1873. Leiden: KITLV Uitgeverij.

Hidding, K.A. 1954. Mens en godsdienst; Levende godsdiensten phaenomenologisch belicht. Delft: Gaade.

Hirosue, Masashi. 1988. Prophets and followers in Batak millenarian responses to the colonial order; Parmalim, Na Siak Bagi and Parhudamdam, 1890-1930. PhD thesis, Australian National University, Canberra.

Hirosue, Masashi. 2005. "The Parmalim movement and its relations to Si Singamangaraja XII; A reexamination of the development of religious movements in colonial Indonesia", Jurnal Antropologi Sosial Budaya Etnovisi 1/3: 113-122.

Hoetagaloeng, Waldemar M. 1926. Poestaha taringot toe tarombo ni Bangso Batak. Lagoeboti: Zendings-Drukkerij. [Reprint: 1991, Pustaha Batak; Tarombo dohot Turiturian ni Bangso Batak. Medan: Tulus Jaya.]

Hutabarat, Kenan, 1925. "Taringot tu Hadatuon", Soara Batak. [In my possession is a typed copy of the text made by Pater Herman Promes in 1964.]

Hutajulu, Norista Rosario. 4-10-2014. “Legenda Pusuk Buhit dan Asal Muasal Si Raja Batak. Newspaper Kompas, Kompasiana”. [Http://www. kompasiana.com/norista_22/legenda-pusuk-buhit-dan-asal-muasal-siraja-batak_54f8f42ba333115f378b4886, accessed on 4-6-2015].

Josselin de Jong, P.E. de. 1957. “[Book review:] Philip Lumban Tobing, The structure of the Toba Batak belief in the High God. PhD thesis, Utrecht University. Amsterdam: Kampen, 1956, 177 pp.", Bijdragen tot de Taal-, Land-en Volkenkunde 113: 393-396. 
Ködding, W. 1885. “Die batakschen Götter und ihr Verhältnis zum Brahmanismus", Allgemeine Missionszeitschrift 12: 401-409, 475-480.

Korn, Victor Emmanuel. 1953. "Batakse Offerande", Bijdragen tot de Taal-, Land- en Volkenkunde 109: 32-51, 97-127.

Kozok, Uli. 1994. Die Klageliedtradition der Batak Nordsumatras. 2 Vols. PhD thesis, University Hamburg.

Loeb, Edwin M. 1935. Sumatra; Its history and people. With an additional chapter by Robert Heine-Geldern. Wien: Institut für Völkerkunde der Universität Wien. [Original edition; Wiener Beiträge zur Kulturgeschichte und Linguistik des Instituts für Völkerkunde der Universität Wien 3.]

Mangardja Salomo Pasariboe. 1925. Barita ni Siboroe Deak Paroedjar (Moela ni djolma dohot tano). Sibolga: Kemadjoean Bangsa.

Mangaradja Salomo Pasariboe. 1938. Tarombo Borbor Morsada. HaoenatasBalige (Lagoeboti): Toba.

Marcks, O. 1930. “Bericht über die 'Häuptlingssprachen' bei den Batak auf Sumatra", Mitteilungen des Seminars für Orientalische Sprachen zu Berlin 33: 131-136.

Meerwaldt, J. H. 1904. Handleiding tot de beoefening der Bataksche Taal. Leiden: Brill.

Modigliani, Elio. 1892. Fra Batacchi Indipendenti; Viaggion di Elio Modigliani. Roma: Societa Geografica Italiana.

Neumann, J.B. 1887. “Het Pane- en Bila-stroomgebied op het eiland Sumatra; Studiën over Batahs en Batahsche landen", Tijdschrift van het Nederlandsch Aardrijkskundig Genootschap IV/3: 217-314.

Niemann, G.K. 1870. “Bijdrage tot de kennis van den Godsdienst der Bataks”, Tijdschrift voor Nederlandsch-Indië 4 (Third Serie): 288-307.

Niessen, Sandra Ann. 1985. Motifs of life in Toba Batak texts and textiles. Dordrecht: Foris. [Verhandelingen van het Koninklijk Instituut voor Taal-, Land- en Volkenkunde 110.]

Parkin, Harry. 1978. Batak fruit of Hindu thought. Madras: The Diocesan Press.

Schärer, Hans. 1963. Ngadju religion; The conception of God among a South Borneo people. The Hague: Martinus Nijhoff. [Die Gottesidee der Ngadju Dajak in Süd-Borneo. PhD thesis, Leiden University, 1946.]

Schefold, Reimar. 2001. "Three sources of blessings in traditional Indonesian societies", Bijdragen tot de Taal-, Land-en Volkenkunde 157: 359-381.

Schefold, Reimar. 2002. "Visions of the wilderness on Siberut in a comparative Southeast Asian perspective", in: G. Benjamin and C. Chou (eds), Tribal communities in the Malay world; Historical, cultural and social perspectives, pp. 422-438. Singapore: Institute of Southeast Asian Studies.

Sinaga, Anicetus Bongsu. 1981. The Toba-Batak High God; Transcendence and immanence. St. Augustin: Anthropos Institute.

Sinaga, Anicetus Bongsu. 1997. Jolma Batak. Gunungsitoli.

Sinaga, Anicetus Bongsu. 2007. Imanat Batak Menyongsong Katolik. Medan: Bina Media Perintis. 
Situmorang, Sitor. 1993. Toba Na Sae; Sejarah ringkas lahirnya institusi-institusi organisasi parbaringin dan dinasti Singamangaraja dalam sejarah suku bangsa Batak-Toba. Jakarta: Sinar Harapan.

Situmorang, Sitor. 2004. Toba Na Sae; Sejarah Lembaga Sosial Politik Abad XIIIXX. Jakarta: Komunitas Bambu.

Stöhr, Waldemar. 1965. “Die Religionen der Altvölker Indonesiens und der Philippinen", in: W. Stöhr and P. Zoetmulder (eds), Die Religionen Indonesiens, pp. 1-221. Berlin, Köln, Mainz: W. Kohlhammer Verlag.

Tampoebolon, Iskandar. 1935. Adat mendirikan hoeta (kampoeng) di Bataklanden. Pematangsiantar: Siregar Philemon.

Tampubolon, Radja Patik. 1964. Pustaha Tumbaga Holing; Adat Batak - Patik/ Uhum. Pematang Siantar.

Tobing, Ph.L. 1956. The structure of the Toba-Batak belief in the High God. Amsterdam: Jacob van Campen.

Tuuk, H.N. van der. 1861. Bataksch-Nederduitsch woordenboek. Amsterdam: Frederik Muller.

Voorhoeve, Petrus. 1927. Overzicht van de volksverhalen der Bataks. PhD thesis, Leiden University.

Voorhoeve, Petrus. 1958. "Batakse buffelwichelarij", Bijdragen tot de Taal-, Land-en Volkenkunde 114: 238-248.

Warneck, Johannes. 1909. Die Religion der Batak; Ein Paradigma für die animistischen Religionen des Indischen Archipels. Leipzig: Dieterich. [Religions-Urkunden der Völker. Abteilung IV Bd. 1.]

Willer, T.I. 1846. "Verzameling der Battahschen wetten en instellingen in Mandheling en Pertibie", Tijdschrift voor Nederlandsch Indië 8/2: 145-424.

Winkler, J. 1925. Die Toba-Batak auf Sumatra in gesunden und in kranken Tagen; Ein Beitrag zur Kenntnis des animistischen Heidentums. Stuttgart: Belser.

Ypes, W.K.H. 1932. Bijdrage tot de kennis van de stamverwantschap, de inheemsche rechtsgemeenschappen en het grondenrecht der Toba- en Dairibataks. Leiden: Adatrechtsstichting. 